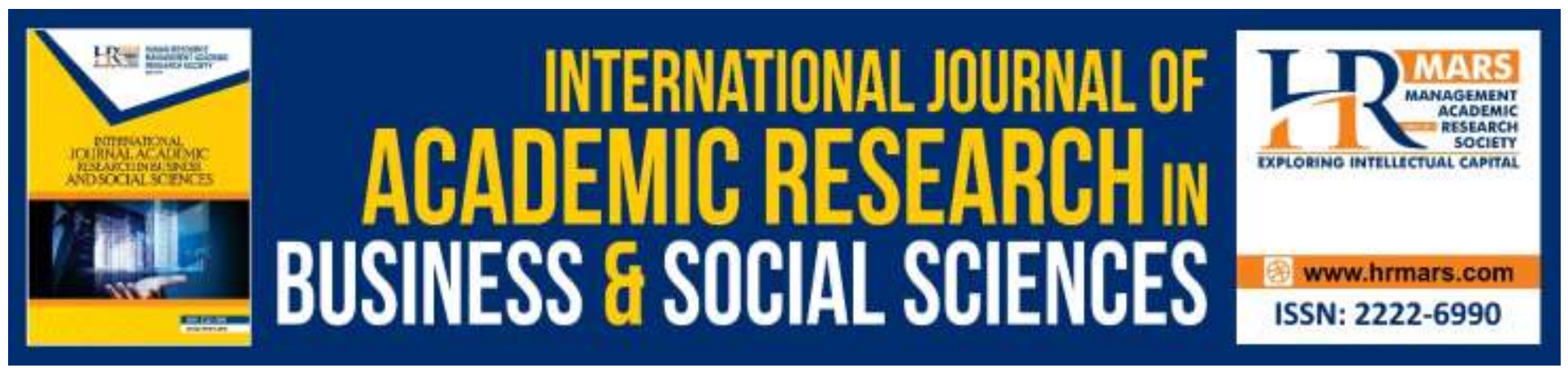

\title{
Comparison of Agility with and without Balls between Players in Position of Defenders, Midfielders and Striker among Sultan Idris Education University (UPSI) Football Players
}

Zulakbal Abd Karim, Mohd Nor Kamali Hassan \& Nazrul Fadzli Khairulhalimi

To Link this Article: http://dx.doi.org/10.6007/IJARBSS/v9-i7/6216

DOI: $10.6007 /$ IJARBSS/v9-i7/6216

Received: 02 May 2019, Revised: 23 June 2019, Accepted: 01 July 2019

Published Online: 25 July 2019

In-Text Citation: (Karim, Hassan, \& Khairulhalimi, 2019)

To Cite this Article: Karim, Z. A., Hassan, M. N. K., \& Khairulhalimi, N. F. (2019). Comparison of Agility With and Without Balls between Players in Position of Defenders, Midfielders and Striker among Sultan Idris Education University (Upsi) Football Players. International Journal of Academic Research in Business and Social Sciences, 9(7), 1081-1099.

Copyright: (C) 2019 The Author(s)

Published by Human Resource Management Academic Research Society (www.hrmars.com)

This article is published under the Creative Commons Attribution (CC BY 4.0) license. Anyone may reproduce, distribute, translate and create derivative works of this article (for both commercial and non-commercial purposes), subject to full attribution to the original publication and authors. The full terms of this license may be seen

at: http://creativecommons.org/licences/by/4.0/legalcode

Vol. 9, No. 7, 2019, Pg. 1081 - 1099

http://hrmars.com/index.php/pages/detail/IJARBSS

JOURNAL HOMEPAGE

Full Terms \& Conditions of access and use can be found at http://hrmars.com/index.php/pages/detail/publication-ethics 


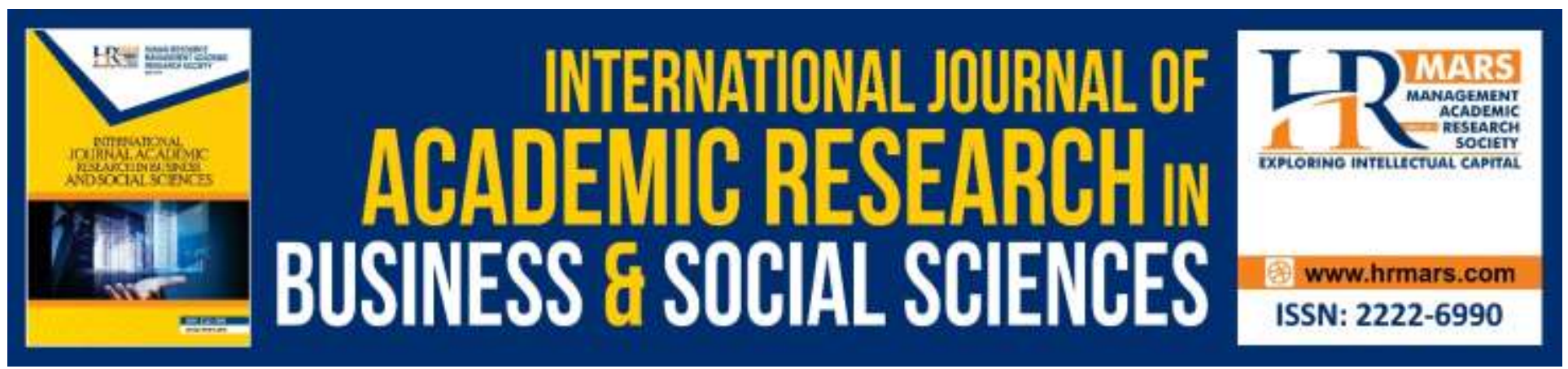

\title{
Comparison of Agility with and without Balls between Players in Position of Defenders, Midfielders and Striker among Sultan Idris Education University (UPSI) Football Players
}

\author{
Zulakbal Abd Karim, Mohd Nor Kamali Hassan \& Nazrul Fadzli \\ Khairulhalimi \\ Faculty of Sport Science and Coaching, Sultan Idris Education University, Tanjong Malim, Perak, \\ Malaysia \\ Email: zulakbal@fsskj.upsi.edu.my
}

\begin{abstract}
This study is aimed to identify the comparison of agility without the balls and using the balls among football players who play in defenders, midfielders and striker in IPT League for Sultan Idris Education University, Tanjong Malim, Perak. The researchers have imposed Illinois Test and Slalom $90^{\circ}$ and $180^{\circ}$ in order to determined the level of subjects agility though pre and post test after undergone the training program. The sample of this study consists of $n=18$ football players. The data was obtained from the subjects scores in this test were analyzed by using One-Way Anova from Statistical Package for Social Science version 21.0. The results of agility without balls among defenders, midfielders and strikers showed the significant difference between defenders position ( $M i n \pm S P=2.22 \pm 0.99$ ), midfielders ( $\mathrm{Min} \pm \mathrm{SP}=34.95 \pm 1.17$ ) and strikers ( $\mathrm{Min} \pm \mathrm{SP}=31.40 \pm 1.36$ ) without using the balls before treatment was given by using agility indicator with value $F(2,12)=6.01, p<0.05$. Meanwhile the results showed that there was a significant difference among defenders Min $\pm S P=29.37 \pm 1.51$ ), midfielders ( $\mathrm{Min} \pm \mathrm{SP}=30.29 \pm 0.93$ ) and strikers ( $\mathrm{Min} \pm \mathrm{SP}=26.11 \pm 0.78$ ) without using balls after received treatment on agility indicator with value $F(2,12)=9.02, p<0.05$. For agility results among football players that consists of defenders, midfielders and strikers before received treatment showed there was no significant difference. However, the test results showed that there was a significant difference with the value 0.000 among defenders, midfielders and strikers with balls after received treatment. As results, it is clearly showed that training program conducted by the subjects in this study has a positive impact in improving the level of agility.
\end{abstract}

Keywords: Football Players, Agility, Illinois Test, Slalom Test, One-Way Anova 
INTERNATIONAL JOURNAL OF ACADEMIC RESEARCH IN BUSINESS AND SOCIAL SCIENCES Vol. 9, No. 7, July, 2019, E-ISSN: 2222-6990 @ 2019 HRMARS

\section{Introduction}

Football is popular game that played around the world. Entering the $21^{\text {st }}$ Century, football have played more than 250 millions people in 200 countries, making it most popular sports in the world. Football is considered as the number one sport in Malaysia based on television audiences, compared to other sporting events viewed (Hamid \& Kendall, 2008; Karim, 2016; Karim \& Nadzalan, 2017; Pundyk, 2004). Football is played by two teams that consists of eleven players of both sides to score the goals by used lower limbs components only. The field is square in shape and played on field grass or synthetic. In football, a player must perform or to act by using force, power, speed, agility, balance, stability, flexibility and endurance. According to Stolen (2005), a football player ran at every corner of the field approximately 10 kilometers in one of the ongoing matches. Where 90 seconds each acceleration is around $11 \%$ of the total activity with each action is average two to four seconds covered a distance of 15 meters. Meanwhile, physical readiness for a football players is a complex process according to Bloomfield, Polman, O’Donoghue, and McNaughton (2007); Gorostiaga, Izquierdo, Ruesta, Iribarren, González-Badillo and Ibáñez (2004); Helgerud, Engen, Wisløff, and Hoff (2001).

In order to enhance the players' performance, a coach is the responsible person to succeed it. According to Karim, Razak, and Nadzalan (2018), a coach plays an important role in improving an individual and team's performance. In addition, Karim and Nadzalan (2017) also stated that a coach needs to have knowledge on coaching in order to help improve their coaching skills. According to Karim (2016), coaches who are more knowledgeable and intelligent in facing the challenges in the process of building their careers as a coach tend to do better in their responses toward every challenge they encounter. These coaches also believed that the education system of coaching education and the aspect of football culture can produce more young coaches who are able to improve until they reach the expert level in the field of football coaching (Karim \& Nadzalan, 2017).

Johnson \& Nelson (1986) have defined that agility is the physical ability of an individual in changing body position and direction accordingly. In addition, agility is the ability to change the direction of movement within given space rapidly and accurately as described by Corbin and Lindsye (1988). Through this definition, it is clearly related to other aspects that influenced it. Beim and George (1977), stated regarding agility that rely on the coordination, strength and reactions of an individual in order to overcome the momentum of weight. The respective aspects such as speed, coordination and precision of the main muscle in implementing the movement that can affect the agility. Agility while running and playing the balls is an emphasis factor which may predict the ability of a player upon his or her motor skills in football. According to Johnson and Nelson (1986), the definition of agility is physical activity that allows a person to change or to shift position and direction rapidly in short time on the move.

According to research by Jullien, Bisch, Largouët, Manouvrier, Carling and Amiard (2008), it is clearly that short-term training programs within three weeks, may increase the level of agility among youth professional football players. This circumstance illustrated that agility is the most important aspect of football according to Jovanovic, Sporis, Omrcen and Fiorentini (2011). Chapman (2008) 
explained that the speed in football consists of the aspects of the run, speed of reaction and speed during acceleration during the first pitch. Through these two aspects showed that speed, agility and pace were the methods of training that must be applied in fitness components in football. There was a significant correlation between acceleration, maximum speed and agility but there was a unique features of each components and might be regarded as no relation to each other according to Little and Williams (2006).

\section{Literature Review}

Pauole, Hodgson, Peterson, Graf-Baumann, Junge, Chomiak and Dvorak (2005) have proved in their study that was a significant performance in the T-Test of agility and acceleration at a distance of 40 yards for both male and female genders. Action in a football such as high speed can be categorized as acceleration requiring acceleration, maximum speed and agility skill according to Gambetta (1996). Meanwhile according to Javanovic, Sporis, Omrcen and Fiorentini (2011), the speed, agility and pace programs did not improve the performance of youth football players during the season when training with the ball and without the ball but it was an effective way to improve certain aspects of power.

According to Seils by Johnson and Nelson (1986) showed high correlation between physical growth and agility among boys and girls at primary level. Based on the previous study which was conducted by Espenschade in Johnson and Nelson (1986) quoted that level of agility among boys and girls were increased at the age of 14 . However, when their age reach 14 years, the level of agility of girls reach the level of decline.

The interrelation of agility with somatotype, was conducted by Solley (1957) in the booklet of Bookwalter (1952) stated that the endomorph were less agility than the somatotype. The comparison between ectomorph and mesomorph caused discrepancy in opinion. According to Bookwalter (1952) stated that boys with moderate body size belong to the ectomorph which have an agile agility, while the opinion expressed by Sil (1953) argued that the mesomorph was more agile than ectomorph. However, it was found that the size of the body at any level of age was not affected the agility through the study was conducted by Solley (1957).

In a study that was conducted by Stone and Bryant (1981) have conducted 17 tests on American Footballers in 21 High Schools. The selected school consists of successful and less successful of mixed schools in this game. Based on 17 tests conducted, the Illinois Agility Run test have been utilized in order to identify the players' ability in sports. The result was obtained from the tests carried out successfully by the trainer's criteria for the players. An agility test known as the SEMO agility test was conducted by Kirby (1971) aimed to measure the level of body agility in changing the direction of movement from multiple angle. Meanwhile in physical fitness test was conducted by AAHPERD (1976), agility component has incorporated in the test. One of the famous of his test which is 10meter shuttle run, where the test aimed to measure the level of agility of the tested subjects in running while changing the direction of movement. 


\section{Problem Statement}

Basically a football player will involve in 2-4 seconds changes of direction and approximately makes $1,200-1,400$ changes of direction during in a single game but it depends on the players (Davids, Lees \& Burwitz, 2000). Therefore, football players need to mastery the agility because its a fundamental physical quality for the optimal performance (Harman, Rosenstein, Frykman \& Rosenstein, 1990). It is believe that there is a lack of research regarding agility comparison among University's athletes in Malaysia. Thus, the purpose of the research is to identify the comparison of agility level without the balls and using the balls among UPSI football players in various positions. To provide information regarding effectiveness of agility tests which consists of Illionois Test and Slalom Test among the football players.

\section{Research Methods}

According to Majid (1993), the research conducted should be based on research methods that are relevant to the objectives of the study and the overall framework of research patterns conducted based on information sources, methods for obtaining information, types of information collected and methods of information processing. This chapter describes the aspects of the population and the sample of the study, design of the study, the study variables, the instruments of the study, the data collection and the data analysis of the Research Design.

In conducting this study, the design of the study was used based on the experimental method involving descriptive testing methods. This study was conducted among football players of Sultan Idris Education University, Tanjong Malim Perak, which represented the University in the League of Higher Education Institutions (IPT League) 2018. The subjects consists of football players in various positions such as defenders, midfielders and even strikers underwent two agility tests which are Illinois Test and the Slalom Test (Sprint whilst 90 and 180 degrees turn). Both tests were performed without the ball and with the ball, where agility of the subjects were judged by the scores they have earned and were recorded in the score sheet. The data were obtained and analyzed in order to identify the significant difference to the agility of defenders, midfielders and strikers among the IPT League football players of Sultan Idris Education University, Tanjong Malim, Perak. One-Way Anova test was used to test the questions of this agility study. 


\section{Research Concept Framework}
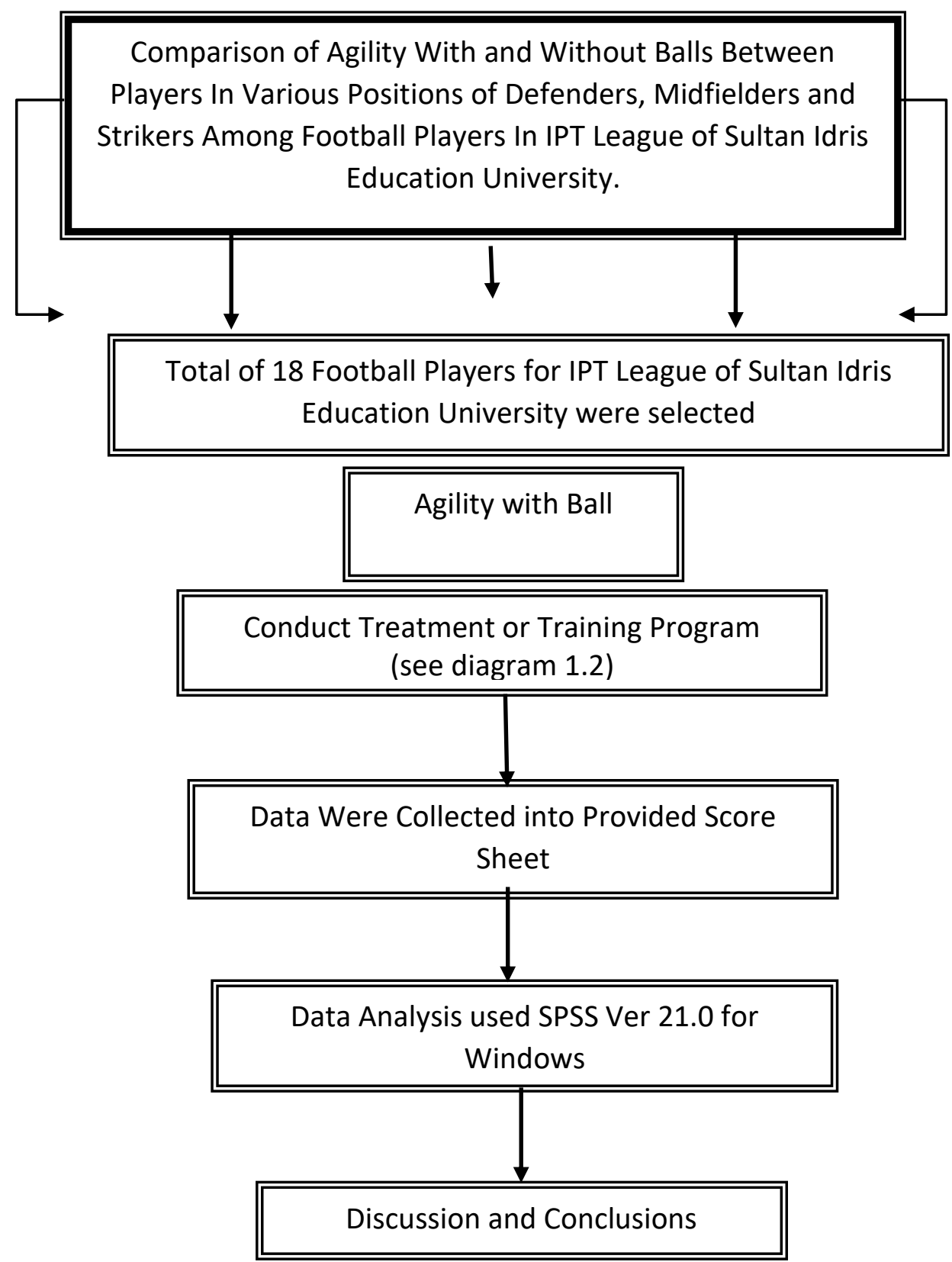

Figure 1.1 : Conceptual Framework for Implementation of the Study 


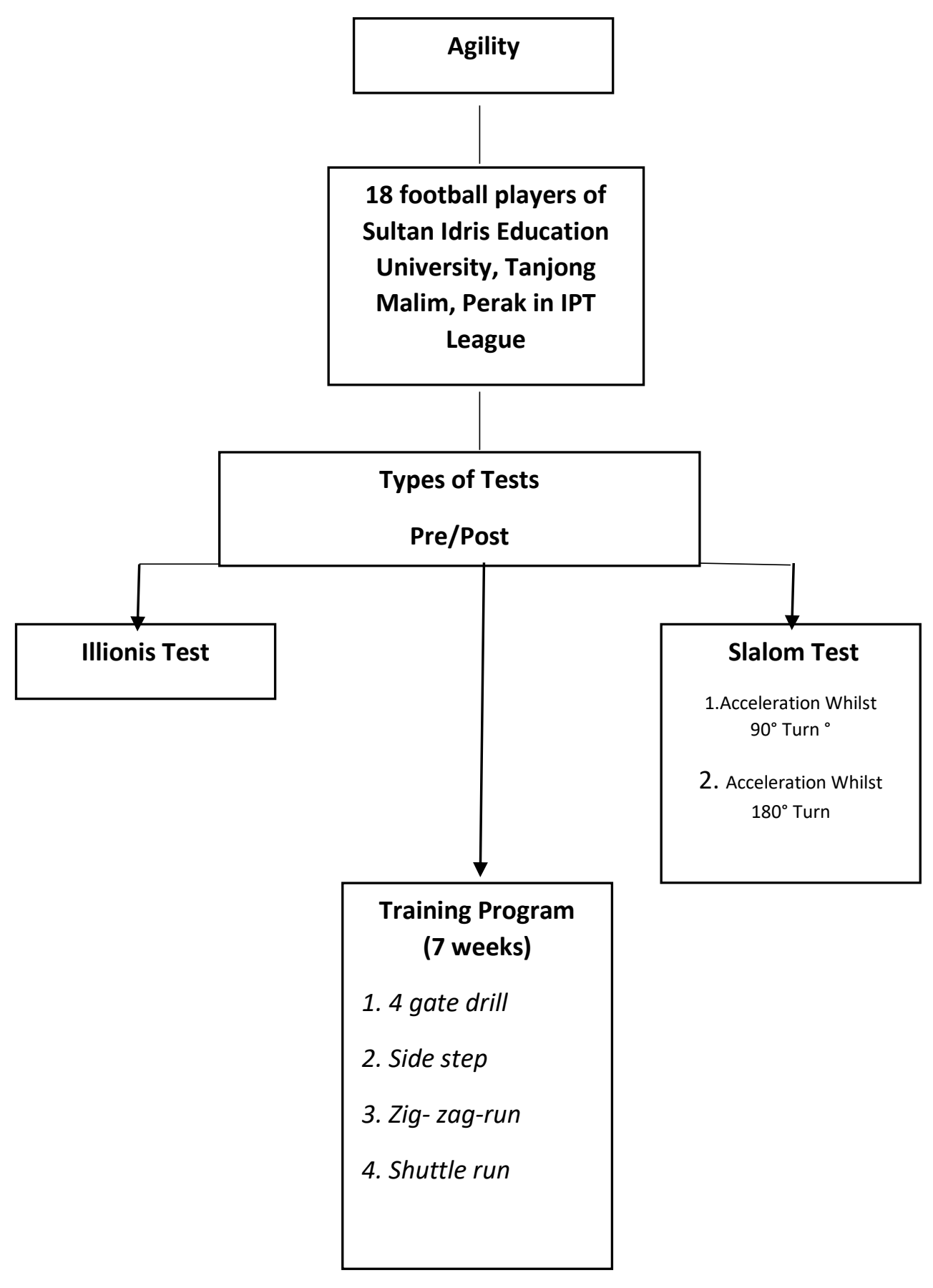

Figure 1.2 : Conceptual Framework Test 


\section{Subject of Study}

The selection of subjects is consists of Sultan Idris Education University's football players which represented the University in IPT League Championship 2018. The study focused on defenders, midfielders and strikers where sample selection were taken based on cluster sampling of 18 football players. The average age of the selected subjects were between 20 to 25 years old.

\section{Instruments of Study}

In this study, the researcher used instrument which involved two tests such as Illinois Test and Slalom Test (turn $90^{\circ}$ and $180^{\circ}$ ) whilst accelerated with the ball. The types of tests were conducted on the agility of an athlete or player in sport participation. Therefore, the researchers have chosen both tests to identified the level of agility between football players in various positions such as defenders, midfielders and strikers among them for Sultan Idris Education University IPT League.

\section{Illinois Test Protocol}

I. The subjects started with warm-up and stretching.

II. Skittle Cone was placed at the designated place as shown.

III. The subjects stand at the starting line with a ball

IV. Once received starting signal, the subject ran 10 meters towards the front line whilst dribbling the ball with foot (see diagram).

V. The subject reverted back to the starting line and then ran around the 4 Skittle Cone that had been set to the specified distance.

VI. The subjects were continuing run until finishing line.

VII. Time was started when the subjects started the run and time was stopped once the subjects arrived at the finishing line.

VIII. The subjects were required to underwent 2 attempts of the test.

IX. The Subjects had to cooling down after the second test was done accordingly. 
INTERNATIONAL JOURNAL OF ACADEMIC RESEARCH IN BUSINESS AND SOCIAL SCIENCES Vol. 9, No. 7, July, 2019, E-ISSN: 2222-6990 @ 2019 HRMARS

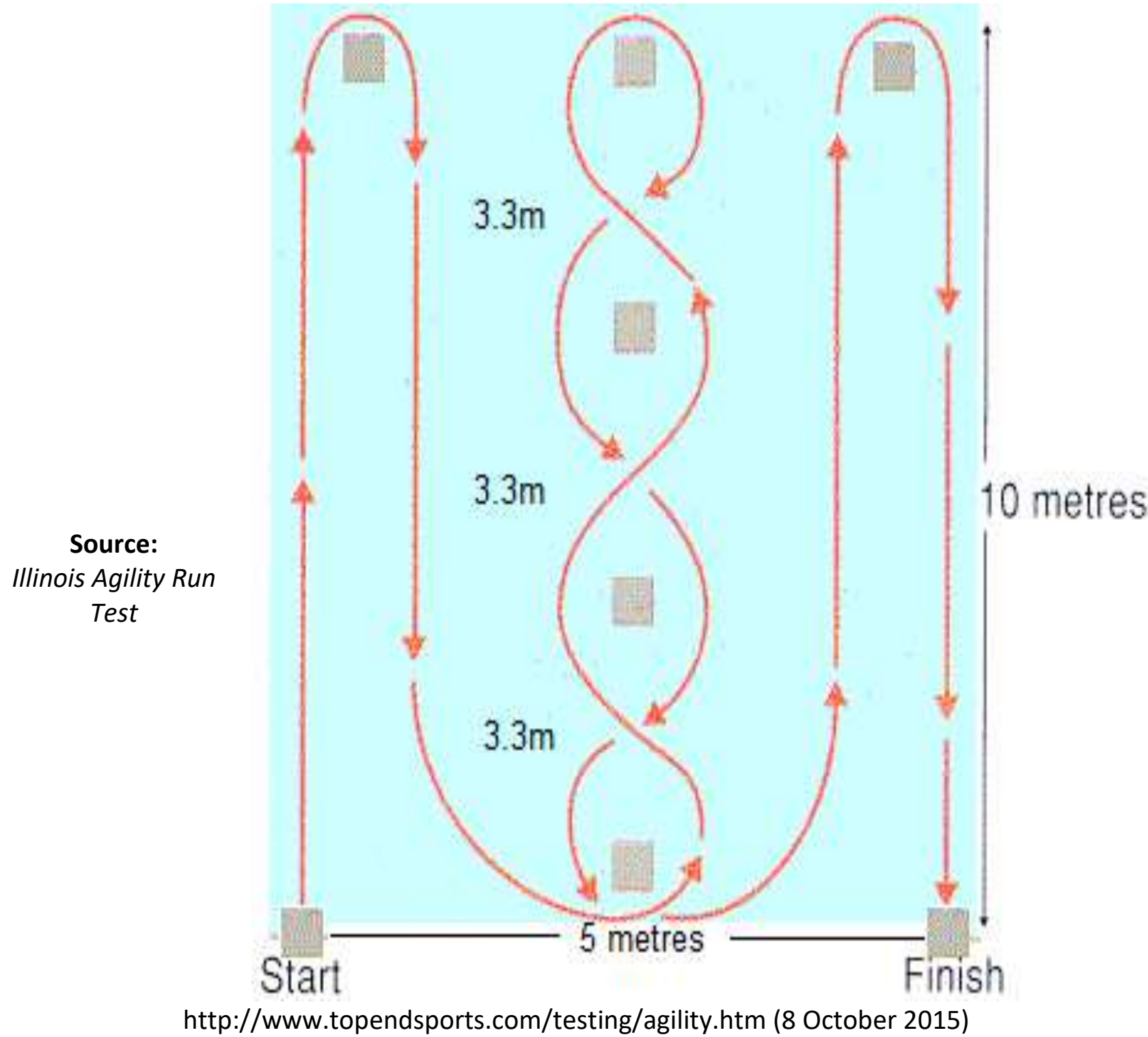

Figure 1.3 : Diagram of Illinois Agility Run Test for Pre and Post Tests. 


\section{Protocol of Slalom $90^{\circ}$ Turn Test with Ball}

I. The subjects were performed body warming and stretching activities.

II. Skittle Cone was placed at the designated place as shown.

III. The subjects stand at the starting line with a ball.

IV. One received the starting signal, the participants ran with the ball from point $A$ to point $B$.

V. Next the subjects made $90^{\circ}$ turn to the right at the point $B$ and ran to point $C$.

VI. At the point $C$, the subject must $90^{\circ}$ turn to the left and ran to point $D$.

VII. Next the subject made $90^{\circ}$ turn to the left and ran to point $\mathrm{E}$.

VIII. Once arrived at point $E$, the subject need to $90^{\circ}$ turn to the right and ran to point $F$. Next, at the point $F$, the subject made $90^{\circ}$ turn to the right and arrived at the point $G$. Then, the subject made final $90^{\circ}$ turn to the left and reached at last point which was point $\mathrm{H}$.

IX. Time was taken when the subject started to ran and was stopped once the subject arrived at the finishing line.

$X$. The subjects were required to underwent 2 attempts of the test.

XI. The Subjects had to cooling down after the both test were done accordingly. 


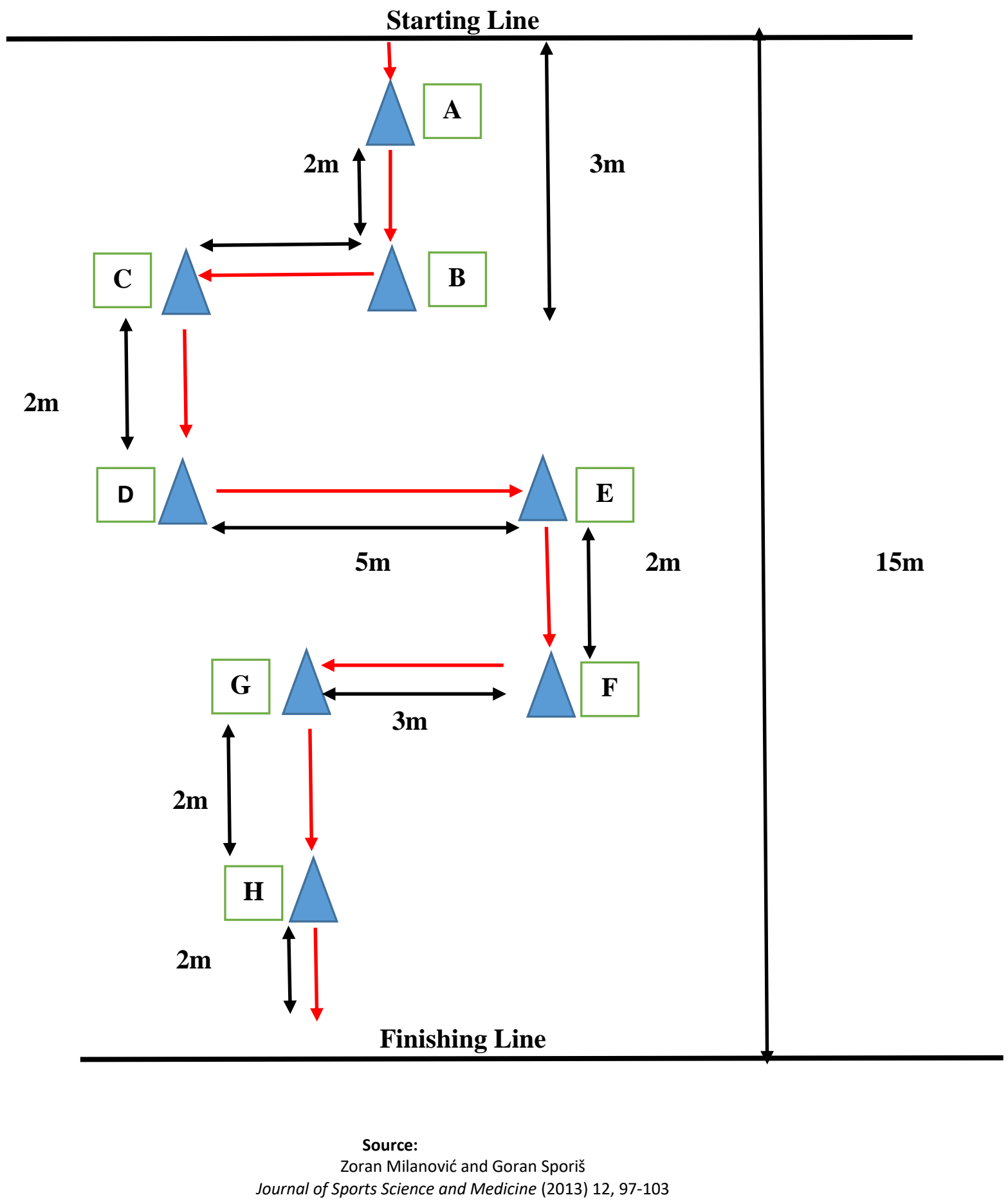

Figure 1.4 : Diagram of Slalom $90^{\circ}$ Turn Test with Ball for Pre and Post Test 


\section{Protocol Of Slalom $180^{\circ}$ Turn Test with Ball}

I. The subject stood at the starting line whilst waited for the instructions to be announced.

II. Once instruction was given, the subject ran as far as 9 meters to the point $B$.

III. Once arrived at the point $\mathrm{B}$, the subject was required to made $180^{\circ}$ turn and then accelerated as far as 3 meters to point $C$.

IV. At the point $\mathrm{C}$, the subject was performed the same activity of $180^{\circ}$ turn and made accelerated as far as 6 meters to the point $D$.

V. At the point $D$, the subject once again made $180^{\circ}$ turn and made accelerated to point $E$ as far as 3 meters. And then, the subject made last $180^{\circ}$ turn at the point $E$ and made accelerated as far as 9 meters to the last point which was point $F$.

VI. The start time was taken when the subject made accelerated at the starting line and was stopped when the subjects arrived at the point $F$. 


\section{Starting Line}

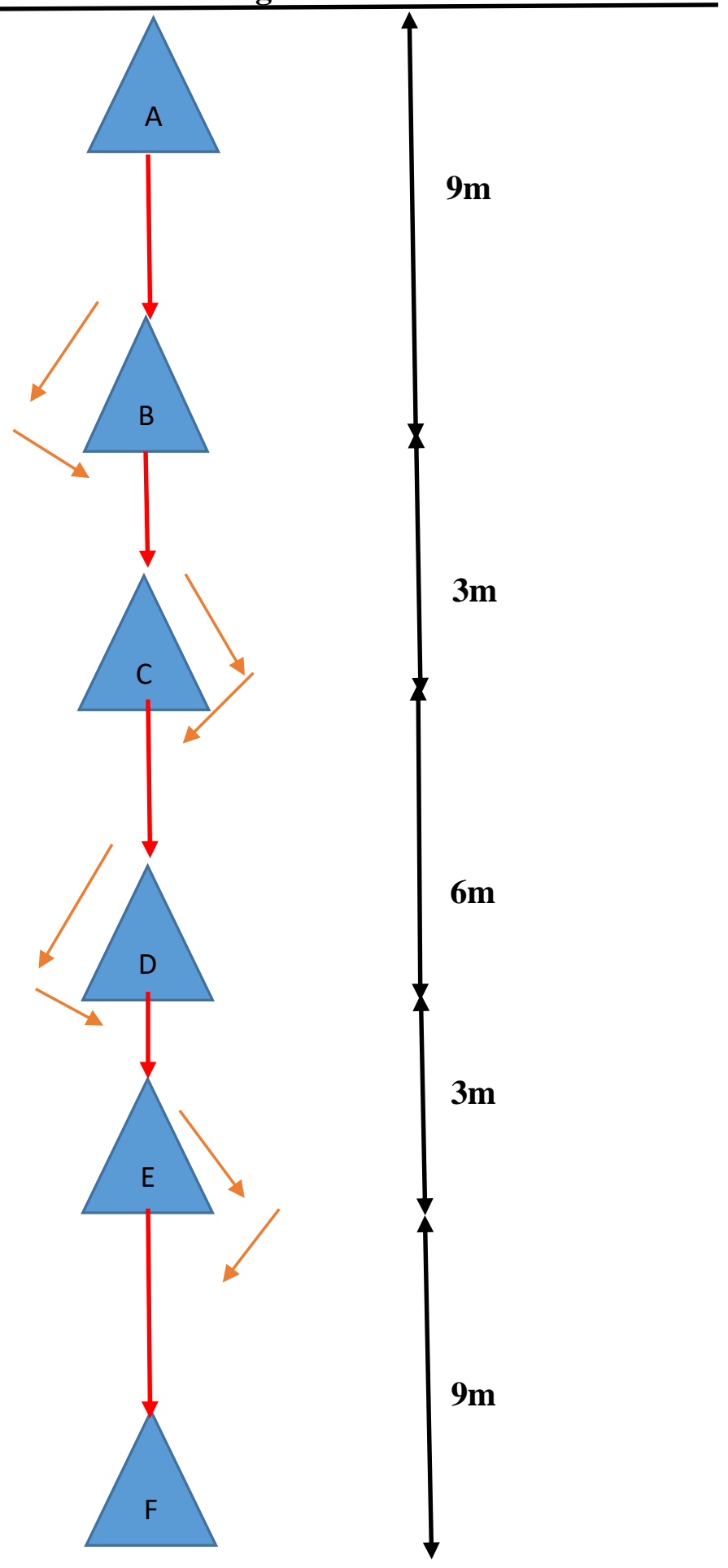

Finishing Line

Figure 1.5 : Diagram of Slalom $180^{\circ}$ Turn Test with The Ball for Pre and Post Test 


\section{The Overall Protocol of Illinois Test and Slalom Test Implementation}

In a study which was conducted by the researchers, two types of tests were used which were Illinois and Slalom tests merely to identify the agility with and without ball between the players in various positions of defenders, midfielders and strikers among the football players of Sultan Idris Education University in IPT League. Each of the tests was performed whether with or without ball where the best time was taken on the basis of twice trial was given to each subjects.

Before the test started, the subjects were performed warm up session which I have appointed one of the subjects to lead the session and was monitored by the researchers. The purpose of the warm up session was to ensure that each subjects was in a state of readiness before perform the test. The subjects were performed the Illinois Test and then followed by Slalom $90^{\circ}$ turn and finally with Slalom $180^{\circ}$ turn. The subjects were given a trial of twice where the subjects were used with and without the ball whilst performed the test. Rest time was given to the subjects for one minute in a test and two minutes for the next test. After performed the test, the subjects were performed cooling down session which lead by a subject for this session.

\section{Management and Administration}

In order to carried out of this study, it was started with a discussion with the coordinator of final year project and supervisory lecturer which related to the research study which were carried out by the researchers. Once verified, research has begun with writing of chapter one until chapter three. Next, the researchers have discussed with the manager and football coach of IPT League Football Team, Sultan Idris Education University, named En Mohd Azmin Bin Abu Hassan and En Firdaus Bin Jasmani in order to seek permission for conducting research on their players as subjects in research study. Once received the cooperation from the University team, the data collection process were conducted through two stages such as Pre Test, Post Test and Program Training for 7 weeks. After the tests were carried out, then the data collections process, data analysis were implemented by using Microsoft Office Excel 2013 and Software of Statistical Package for Social Science (SPSS) version 21.0.

\section{Data Analysis}

Based on the research that was conducted by the researcher, the data analysis was done accordingly with the tabulation of data scores which was obtained via the test and the data was collected by the researcher. Next, data was analyzed by using SPSS/PC Program and was descriptive on score sheet which raw scores were analyzed and labeled in percentage, mean, standard deviation and via OneWay Anova test was used in order to identify the related research questions regarding the comparison of agility level with and without ball between the players in positions of defenders, midfielders and strikers among football players in IPT League of Sultan Idris Education University Tanjong Malim, Perak. 
INTERNATIONAL JOURNAL OF ACADEMIC RESEARCH IN BUSINESS AND SOCIAL SCIENCES Vol. 9, No. 7, July, 2019, E-ISSN: 2222-6990 @ 2019 HRMARS

Figure 1.6 : Diagram 4.1

One-Way Anova based on Agility Test without ball between Defenders, Midfielders and Strikers Before Treatment.

\begin{tabular}{lccccc}
\hline & $\begin{array}{c}\text { Sum of } \\
\text { Squares }\end{array}$ & df & $\begin{array}{c}\text { Mean } \\
\text { Square }\end{array}$ & Value F & Significant \\
\hline Between Group & 32.74 & 2 & 16.37 & 6.02 & $\mathbf{0 . 0 1 5}$ \\
Within Group & 32.68 & 12 & 2.73 & & \\
\hline
\end{tabular}

Figure 1.7 : Diagram 4.2

One-Way Anova based on Agility Test without ball between Defenders, Midfielders and Strikers After Treatment.

\begin{tabular}{lccccc}
\hline & $\begin{array}{c}\text { Sum of } \\
\text { Squares }\end{array}$ & df & $\begin{array}{c}\text { Mean } \\
\text { Square }\end{array}$ & Value F & Significant \\
\hline Between Group & 80.70 & 2 & 40.35 & 9.02 & $\mathbf{0 . 0 0 4}$ \\
Within Group & 53.71 & 12 & 4.48 & & \\
\hline
\end{tabular}


INTERNATIONAL JOURNAL OF ACADEMIC RESEARCH IN BUSINESS AND SOCIAL SCIENCES

Vol. 9, No. 7, July, 2019, E-ISSN: 2222-6990 (C) 2019 HRMARS

Figure 1.8 : Diagram 4.3

One-Way Anova based on Agility Test with ball between Defenders, Midfielders and Strikers Before Treatment.

\begin{tabular}{lccccc}
\hline & $\begin{array}{c}\text { Sum of } \\
\text { Squares }\end{array}$ & df & $\begin{array}{c}\text { Mean } \\
\text { Square }\end{array}$ & Value F & Significant \\
\hline Between Group & 27.04 & 2 & 13.52 & 2.07 & 0.169 \\
Within Group & 78.50 & 12 & 6.42 & & \\
\hline
\end{tabular}

Figure 1.9 : Diagram 4.4

One-Way Anova based on Agility Test with ball between Defenders, Midfielders and Strikers After Treatment.

\begin{tabular}{lccccc}
\hline & $\begin{array}{c}\text { Sum of } \\
\text { Squares }\end{array}$ & df & $\begin{array}{c}\text { Mean } \\
\text { Square }\end{array}$ & Value F & Significant \\
\hline Between Group & 48.31 & 2 & 24.16 & 19.50 & $\mathbf{0 . 0 0 0}$ \\
Within Group & 14.87 & 12 & 1.24 & & \\
\hline
\end{tabular}

\section{Discussion}

Generally, the test model was implemented in order to test the comparison of agility with and without using the ball among IPT League football players. Therefore, the researcher has insisted to identify the football players agility level with and without using the ball. This study was also conducted in order to guide the coaches in term of training pattern process which could give positive implication to improve the fitness level among football players especially in agility aspect because most of the these days coaches are lack of emphasis on agility during training session and they are more concern with tactical aspects rather than football players fitness. Hence, the coach must know the importance of agility aspect in current world of football. Each football players have different level of agility, as a coach should make an appropriate and effective approach in enhancing the agility level among football players. Various tests can be performed for agility but this study only focus on two tests such as Illinois Test and Slalom Test. 


\section{Conclusion}

Based on the research that was carried out with the limitations, we can conclude that there were significant differences between all positions such as defenders, midfielders and strikers in agility without balls whether before and after received treatment including with the balls after receive treatment. There was no significant difference only with balls before received treatment. In a nutshell, it is clearly showed that training program conducted by the subjects in this research has a positive impact in improving the level of agility among the UPSI football players in IPT League.

It is vital to all athletes in various sports background to be tested by using agility test in order to identify and to explore the agility level of the athletes accordingly. As a result, coaches may improve the agility area towards their athletes if necessary. Athletes need to be mastery in movement in different directions within confined space in order to produce solid performance accordingly (Bloomfield, Polman \& O'Donoghue, 2007). According to Haj-Sassi, Dardouri, Gharbi, Chaouachi and Mansour (2011) ; Pauole, Madole, Garhammer, Lacourse \&, Rozenek (2000) basically in training program focus more on improving change of direction speed among footballers.

\section{Suggestions}

Through this research which enable the other researchers to give them some input in their upcoming research and coaches might to apply the agility test among their athletes in various sports background. For the athletes, they have to improve their agility's ability from time to time accordingly in order to keep their performance in good shape. Since in this research the agility test only apply Illinois Test and Slalom Test, it is recommend to apply the various types of agility test for the future purpose.

Ethical clearance - The study has been done in accordance with human research ethics as per required by the Declaration of Helsinki. 
INTERNATIONAL JOURNAL OF ACADEMIC RESEARCH IN BUSINESS AND SOCIAL SCIENCES

Vol. 9, No. 7, July, 2019, E-ISSN: 2222-6990 @ 2019 HRMARS

\section{References}

AAHPERD, (1976). Youth Fitness Test Manual. American Alliance for Health, Physical Education and Recreation. Washington, D.C. (119).

George, B. D. (1977). Principle of Modern Soccer Boston: Houghton Mifflin Co. World Cup Sport, Inc Bloomfield, J., Polman, R., O'Donoghue, P. and McNaughton, L. (2007). Effective speed and agility conditioning methodology for random intermittent dynamic type sports. The Journal of Strength and Conditioning Research, 21(4), 1093-1100.

Bloomfield JTR, Polman, R., O'Donoghue, P. (2007) Physical demands of different positions in FA premier league soccer. J Sports Sci Med 6: 63-70.

Chapman, S., Derse, E. and Hansen, J. (2008). Soccer Coaching Manual. Los Angeles: LA84 Foundation. Single chapman

Corbin, C. B. and Lindsey, R. (1988). Concepts of Physical Education with Laboratories (6thed.). Englewood Cliffs, N.J.: Prentice- Hall.

Davids, K, Lees, A., Burwitz, L. (2000) Understanding and measuring coordination and control in kicking skills in soccer. Implications for talent identification and skill acquisition. J Sports Sci 18: 703-714.

Gambetta, V. (1996). In a blur: How to develop sport-specific speed. Sports Coach 19(3), 22-24.

Gorostiaga, E. M., Izquierdo, M., Ruesta, M., Iribarren, J., González-Badillo, J. J. and Ibáñez, J. (2004). Strength training effects on physical performance and serum hormones in young soccer players. European Journal of Applied Physiology 91, 698-707.

Hamid, N. H. A., \& Kendall, G. (2008). Maximising stadium attendance: A case study of

Malaysian football. Proceedings of the 7th International Conference on the Practice and Theory of Automated Timetabling PATAT (pp. 1-4). Montreal: Université de Montréal.

Harman, E., Rosenstein, M., Frykman, P., Rosenstein, R. (1990) The effects of arm and countermovement on vertical jumping. Med Sci Sports Exerc 22: 825-833

Johnson, B. L., Nelson, D. J. K. (1986). Practice Measurement for Evaluation in Physical Education (3rded.). Minnesota: Burgess Publishing Company.

Jovanovic, M., Sporis, G., Omrcen, D. and Fiorentini, F. (2011). Effects of speed, agility, quickness training method on power performance in elite soccer players. The Journal of Strength and Conditioning Research 25(5), 1285-1292.

Jullien, H., Bisch, C., Largouët, N., Manouvrier, C., Carling, C. J. and Amiard, V. (2008). Does a short period of lower limb strength training improve performance in field-based tests of running and agility in young professional soccer players? The Journal of Strength and Conditioning Research 22(2), 404-411.

Karim, Z. A., Razak, A. N. A., \& Nadzalan, A. M. (2018). Designing model of career path development for National Football Development Program (NFDP): directions, issues, challenges and sources of knowledge that influence and develop coaching expertise level. International Journal of Academic Research in Business and Social Sciences, 8(3), 542-550.

Karim, Z. A. \& Nadzalan, A. M. (2017). Malaysian Football Coaches : Development characteristics. International Journal of Academic Research in Business and Social Sciences, 7(9), 305-312. https://doi.org/10.6007/IJARBSS/v7- 
INTERNATIONAL JOURNAL OF ACADEMIC RESEARCH IN BUSINESS AND SOCIAL SCIENCES

Vol. 9, No. 7, July, 2019, E-ISSN: 2222-6990 @ 2019 HRMARS

Karim, Z. A. (2016). Malaysian football coaches: The key challenges. International Journal of Health, Physical Education and Computer Science in Sports, 24(1), 18-24.

Karim, Z. A. (2016). Development characteristics of football coaches in Australia and Malaysia. Doctoral dissertation, Victoria University

Kirby, R. F. (1971). A simple test of agility. Coach and Athlete, June, 30-31.

Little, T. and Williams, A. G. (2006). Specificity of acceleration, maximum speed and agility in professional soccer players. The Journal of Strength and Conditioning Research 19(1), 76-78.

Konting, M. M. (1993). Kaedah Penyelidikan Pendidikan. Kuala Lumpur: Dewan Bahasa dan Pustaka.

Pauole, Hodgson, R., Peterson, T. L., Graf-Baumann, T., Junge, A., Chomiak, J. and Dvorak, J. (2005). Assessment and evaluation of football performance. The American Journal of Sports Medicine28(Suppl. 5), S29-S39.

Pauole, K. K., Madole, J., Garhammer, M., Lacourse, M., Rozenek, R. (2000) Reliability and validity of the T-test as a measure of agility, leg power, and leg speed in college-aged men and women. J Strength Cond Res 14: 443-450.

Pundyk, G. (2004). Welcome to Malaysia. Singapore: Times Editions

Solley, (1957). and Sill, (1953). Investigation of anthropometric and work-rate profiles of elite South American international soccer players. Journal of Sports Medicine and Physical Fitness 40(2), 162-169.

Stone, M., and O'Bryant H. (1981). Weight Training: A Scientific Approach. Minneapolis: Burgess.

Karim, Z. A., Hassan, M. N. K., \& Khairulhalimi, N. F. (2019). Comparison of Agility With and Without Balls between Players in Position of Defenders, Midfielders and Striker among Sultan Idris Education University (Upsi) Football Players. International Journal of Academic Research in Business and Social Sciences, 9(7), 654-669.

\section{Corresponding Author}

Zulakbal Abd Karim

Faculty of Sport Science and Coaching, Sultan Idris Education University, Tanjong Malim, Perak, Malaysia

Email: zulakbal@fsskj.upsi.edu.my 